\title{
Growing Media and Nutrient Solution Concentration Affect Vegetative Growth and Nutrition of Laelia anceps Lindl.
}

\author{
Nadia Jiménez-Peña \\ Instituto de Horticultura, Universidad Autónoma Chapingo, Carr. México- \\ Texcoco km 38.5, Chapingo, México, 56230
}

Luis A. Valdez-Aguilar ${ }^{1}$

Departamento de Horticultura, Universidad Autónoma Agraria Antonio Narro, Calzada Antonio Narro 1923, Saltillo, Coah., México, 25315

Ana M. Castillo-González and María T. Colinas-León

Instituto de Horticultura, Universidad Autónoma Chapingo, Carr. MéxicoTexcoco km 38.5, Chapingo, México, 56230

Andrew D. Cartmill

Pioneer Farm, School of Agriculture, University of Wisconsin-Platteville, 1 University Plaza, Platteville, WI 53818

\section{Donita L. Cartmill \\ School of Agriculture, University of Wisconsin-Platteville, 1 University Plaza, Platteville, WI 53818}

Additional index words. fertilizer rate, nutrient ratios, osmotic potential, substrates

\begin{abstract}
The domestication of wild orchids for commercial production is a new endeavor, which may represent a sustainable alternative to the collection/harvest from natural populations of threatened or endangered orchid species. In the present study, the growth and nutrition of vegetative plants of Laelia anceps Lindl. as affected by three components of the growing medium (peat, volcanic rock, and/or horticultural grade charcoal) and the nutrient solution concentration, measured as osmotic potential $\left(\psi_{s}\right)$, were assessed using mixture experiments methodology. Leaf dry mass (DM) was the highest when plants were irrigated with nutrient solutions of $-0.076 \mathrm{MPa}$. The lower leaf DM at lower or higher $\psi_{\mathrm{S}}$ was influenced by the medium because plants grown in $100 \%$ volcanic rock exhibited no effect, whereas plants grown in either $100 \%$ charcoal or $100 \%$ peat had a marked reduction. Regardless of the $\psi_{s}$ of the nutrient solution, the highest leaf DM was observed in mixtures of two components containing charcoal and peat at high proportions. Dry mass of pseudobulbs and roots was highest in plants irrigated with solutions of $-\mathbf{0 . 0 5 1} \mathrm{MPa}$, especially in mixtures with charcoal or $100 \%$ peat. Decreasing the $\psi_{\mathrm{S}}$ of the nutrient solution resulted in increased shoot nitrogen $(\mathrm{N})$ and potassium $(\mathrm{K})$ concentrations and decreased concentration of phosphorus $(\mathrm{P})$, calcium $(\mathrm{Ca})$, magnesium $(\mathrm{Mg})$, boron $(\mathrm{B})$, manganese $(\mathrm{Mn})$, zinc $(\mathrm{Zn})$, and copper $(\mathrm{Cu})$. Increasing charcoal proportion in the growing media resulted in increased plant iron (Fe) and $\mathrm{Cu}$ concentration. However, increasing volcanic rock reduced plant $P$ and $K$ and increased $M n$ concentration. A higher proportion of peat was correlated with a decrease in plant $\mathrm{Fe}$ concentration. Leaf DM fit models on which macronutrient:micronutrient or micronutrient:micronutrient ratios were calculated, suggesting that nutrient imbalance may be responsible for a plant's responses. The coefficients with the higher values included a micronutrient:micronutrient ratio, suggesting that an extremely fine balance in the uptake of a given micronutrient in relation to other micro- or macronutrient is of major importance for adequate growth of Laelia.
\end{abstract}

The Orchidaceae family contains more than 20,000 species distributed around the world (Molgo and De Dijn, 2007), $\approx 1200$ of

Received for publication 29 Jan. 2013. Accepted for publication 24 Apr. 2013.

${ }^{1}$ To whom reprint requests should be addressed; e-mail luisalonso.valdez@uaaan.mx. and fragrance. When in season, large numbers of $L$. anceps flower stalks and those of other Laelia species are harvested from the wild for a variety of festivals, including weddings and other religious ceremonies (ÁvilaDíaz and Oyama, 2007). Over time, collection/ harvesting of flowers and plants from the wild has threatened the sustainability of $L$. anceps to the point of near extinction in certain regions. Ortega-Loeza et al. (2011) reported that L. speciosa (H.B.K.) Schltr. is threatened as a result of overcollection and loss of natural habitat through deforestation. Environmental agencies in México have been, with limited success, trying to protect $L$. anceps and other orchid species against illegal collection/ harvesting (Ávila-Díaz et al., 2009). Unfortunately, harvesting of flowers and plants from natural populations continues in certain regions.

In México, the domestication of wild orchids for commercial production, a relatively new endeavor, may represent a sustainable alternative to the collection/harvest of these flowers from natural populations. However, commercial cultivation of newly introduced orchids can be tricky and requires sound management practices to attain economic success. The interaction between nutrients in the media solution and the physical and chemical properties of the growing media may affect the response of plants to a specific substrate and nutrient solution formulation.

Tree bark is a traditionally used media for orchid cultivation in México as well as in the United States (Wang and Konow, 2002). However, when bark is mixed with other substrate components of higher water-holding capacity, for example peat and vermiculite, better growth and flower quality are attained (Wang, 1998). In addition, the nutrient requirements of orchids were thought to be relatively low because they respond slowly to fertilization. However, studies have demonstrated that Phalaenopsis Blume and Dendrobium Sw. respond well to fertilization as indicated by increased growth rate and plant quality (Wang, 1995, 1996; Wang and Konow, 2002). Thus, nutrition and growing media selection are critical factors for commercial production of orchids. Unfortunately, information on fertilization and substrate preparation for the cultivation of orchids is limited and not necessarily supported by the literature (Wang and Konow, 2002).

The objective of the present study was to investigate the response of $L$. anceps to media composition (charcoal, volcanic rock, and peat) and nutrient solution concentration (in terms of $\psi_{\mathrm{S}}$ ) to serve as a basis for the commercial production of this threatened species.

\section{Materials and Methods}

which are found in México (Espejo-Serna and López-Ferrari, 1998; Soto, 1998), including 11 species of Laelia Lindl. Laelia anceps Lindl. is an epiphytic orchid that naturally occurs in the oak forests of the central and southern regions of the country. In the fall and winter, L. anceps produce flower stalks bearing white or pink flowers ( 8 to $10 \mathrm{~cm}$ in diameter) of exceptional beauty
Cultural conditions. The experiment was conducted under glasshouse conditions in México (lat. 19 $29^{\prime} 05^{\prime \prime} \mathrm{N}$, long. and $98^{\circ} 53^{\prime} 11^{\prime \prime} \mathrm{W}$ ) from 1 May to $15 \mathrm{Dec}$. 2007. The glasshouse was equipped with a fog system for relative humidity control and a heater for temperature control. Average temperature and relative humidity for the 
duration of the experiment were $22.5 \pm 7.5^{\circ} \mathrm{C}$ (maximum $30{ }^{\circ} \mathrm{C}$, minimum $15{ }^{\circ} \mathrm{C}$ ) and $80 \% \pm 20 \%$ (maximum $100 \%$, minimum $55 \%$ ), respectively. The experimental site was shaded with a $60 \%$ shadecloth, rendering an average photosynthetically active radiation of $227 \mu \mathrm{mol} \cdot \mathrm{m}^{-2} \cdot \mathrm{s}^{-1}$. Micropropagated 15 -month-old L. anceps liners, 9 to $10 \mathrm{~cm}$ in height, with four to six pseudobulbs and four to six leaves, were planted in $15-\mathrm{cm}(2.04-\mathrm{L})$ standard pots. Pots were filled with $1.80 \mathrm{~L}$ of the media and plants were allowed to establish for $7 \mathrm{~d}$ before experiment initiation.

Growing media. The growing media selected for the study were a mixture of three components: horticultural-grade charcoal (1 to $2 \mathrm{~cm}$ in diameter), volcanic rock ( 1 to $2 \mathrm{~cm}$ in diameter), and medium-length fiber peat, which were mixed at varying proportions $(\mathrm{v} / \mathrm{v})$. The growing media was designed using mixture experiments methodology and are expressed as a fraction in Figure 1; the total volume of the mixed components was maintained constant, and the sum of all the fractions must be equal to one. Thus, the response of plants to the mixtures depends only on the proportions of the components (Cornell, 2002). Physical and chemical properties of the three components are shown in Table 1. Before transplanting, the $\mathrm{pH}$ of the 13 resulting mixtures of charcoal:volcanic rock:peat was adjusted to 6.3 to 6.5 with dolomitic limestone or agricultural-grade sulfur. proportion of each component present in the

The response to the mixtures is represented in an equilateral triangle (Fig. 1) on which each vertex corresponds to one component. On the sides of the triangle, there are the binary mixtures that contain two of the mixture components, whereas in the interior, there are the tertiary blends with mixtures containing the three components at varying proportions.

Nutrient solutions. The nutrient solutions were a modified complete Hoagland's formulation (in meq. $\mathrm{L}^{-1}: 12 \mathrm{NO}_{3}^{-}, 3 \mathrm{NH}_{4}^{+}$, $1 \mathrm{H}_{2} \mathrm{PO}_{4}{ }^{-}, 8 \mathrm{Ca}^{2+}, 6 \mathrm{~K}^{+}, 4 \mathrm{Mg}^{2+}, 8 \mathrm{SO}_{4}{ }^{2-}$, and $5 \mathrm{mg} \cdot \mathrm{L}^{-1} \mathrm{Fe}$ ) with increasing concentrations of macronutrients and Fe: $66 \%, 100 \%$, and $133 \%$ of the complete Hoagland's solution, which rendered an $\psi_{\mathrm{S}}$ of $-0.051,-0.076$, and $-0.101 \mathrm{MPa}$, respectively. Electrical conductivity (EC) of the nutrient solutions was $1.42,2.11$, and $2.81 \mathrm{dS} \cdot \mathrm{m}^{-1}$, respectively. Boron, $\mathrm{Zn}, \mathrm{Cu}$, and $\mathrm{Mn}$ were maintained constant in the nutrient solutions at 0.50 , $0.50,0.02$, and $0.65 \mathrm{mg} \cdot \mathrm{L}^{-1}$, respectively. Municipal water $\left(\mathrm{EC}=0.76 \mathrm{dS} \cdot \mathrm{m}^{-1}, \psi_{\mathrm{S}}=\right.$ $-0.027 \mathrm{MPa}$ ) was used to prepare the nutrient solutions. Fertilizer salts were added to the irrigation water to reach the selected $\psi_{\mathrm{S}}$. The $\mathrm{pH}$ of the nutrient solutions was adjusted to 6.0 with sulfuric acid $0.1 \mathrm{~N}$. Throughout the experiment, plants were manually irrigated as needed with one of the three nutrient solutions.

The experiment fulfilled mixture experiments methodology with a simplex-centroid design augmented with six interior points

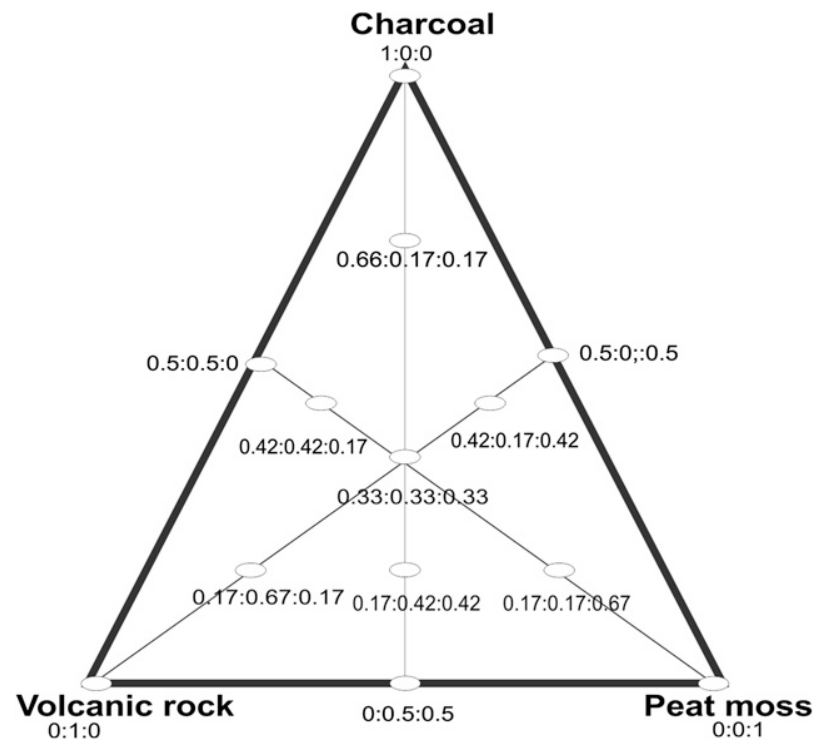

Fig. 1. Design points corresponding to the mixtures of charcoal: volcanic rock: peat evaluated in terms of their proportion in the growing media. The growing media were assessed at three increasing fertilizer ratios measured as osmotic potential $\left(\psi_{\mathrm{S}}\right)-0.051,-0.076$, and $-0.101 \mathrm{MPa}$.

Table 1. Physical and chemical properties of the growing media components evaluated.

\begin{tabular}{lccc}
\hline & Charcoal & Volcanic rock & Peat \\
\hline Solid space (\%) & 31.5 & 31.1 & 22.3 \\
Total pore space (\%) & 68.5 & 68.9 & 77.7 \\
Water-holding capacity (\%) (by volume) & 21.7 & 20.1 & 70.0 \\
Air capacity (\%) & 46.9 & 48.8 & 7.90 \\
Apparent density $\left(\mathrm{g} \cdot \mathrm{cm}^{-3}\right)$ & 0.35 & 0.96 & 0.15 \\
Bulk density $\left(\mathrm{g} \cdot \mathrm{cm}^{-3}\right)$ & 1.12 & 3.08 & 0.73 \\
Electrical conductivity $\left(\mathrm{dS} \cdot \mathrm{m}^{-1}\right)$ & 1.59 & 0.27 & 0.56 \\
Cation exchange capacity $[\mathrm{cmol}(+) / \mathrm{kg}]$ & 12.9 & 4.9 & 51.3 \\
\hline
\end{tabular}

(Cornell, 2002). Each point in the triangle of Figure 1 corresponds to one of the 13 media mixtures, whereas the $\psi_{\mathrm{S}}$ of the nutrient solution was used as a process variable with the three levels mentioned.

Assessment of plant growth. Plants were harvested $180 \mathrm{~d}$ after experiment initiation and separated into leaves, pseudobulbs, and roots. Plant parts were washed twice in distilled water, placed in paper bags, dried in an oven at 60 to $65{ }^{\circ} \mathrm{C}$ for $5 \mathrm{~d}$, and the DM of leaves, pseudobulbs, and roots was determined. Plants parts were ground to pass a 40-mesh screen and for shoot tissue analysis, a mixture composed of the dry tissues from the leaves and pseudobulbs was prepared. The analysis included: N, P, K, Ca, $\mathrm{Mg}, \mathrm{Fe}, \mathrm{B}, \mathrm{Cu}$, and $\mathrm{Zn}$. Nitrogen was determined by the Kjeldahl procedure and the remaining elements by inductively coupled plasma mass spectrometry (model Liberty; VARIAN, Santa Clara, CA).

Statistical design and analysis. Plant responses to the growing media and $\psi_{\mathrm{S}}$ of the nutrient solutions were analyzed using Design Expert ${ }^{\odot}$ Version 6.0.4. Statistical models were selected using adjusted $R^{2}$ and the model with fewer and significant terms $(P<0.05)$ to estimate optimum mixture of medium components and $\psi_{\mathrm{S}}$ of the nutrient solution. The mixtures combined with the nutrient solutions resulted in 39 treatments, which, along with the four one-plant replications, were arranged in a randomized block design. Pairwise shoot nutrient concentration ratios were regressed to estimate the linear models that best explained leaf DM. These models were selected using backward elimination of model terms with SAS Version 8.0 (SAS Institute, Inc., 2001). Nutrient concentrations were statistically analyzed using analysis of variance and Tukey's multiple comparison test with $P<0.05$.

\section{Results}

Leaf DM was affected by the $\psi_{\mathrm{S}}$ of the nutrient solution and the growing media (Table 2). According to the models, leaf DM was the highest when plants were irrigated with a solution of $-0.076 \mathrm{MPa}$. Lower or higher $\psi_{\mathrm{S}}$ had a deleterious effect on leaf DM (Fig. 2A-C). Furthermore, smaller leaf $\mathrm{DM}$ at the lower or higher $\psi_{\mathrm{s}}$ was influenced by the medium mixtures as plants grown in $100 \%$ volcanic rock exhibited no effect, whereas plants grown in either $100 \%$ charcoal or $100 \%$ peat had a lower leaf DM. Regardless of the $\psi_{\mathrm{S}}$ of the nutrient solution, the highest leaf DM was observed in mixtures of two components containing higher proportions charcoal and peat. The media in which plants produced greater than $80 \%$ of maximum leaf DM are shown in the shaded area of the counterplot in Figure 2B.

The $\psi_{\mathrm{S}}$ of the nutrient solution and the substrate mixes affected the growth of pseudobulbs (Table 2). Higher $\psi_{\mathrm{S}}$ of the nutrient solution resulted in lower pseudobulbs DM but it was more affected when plants were grown in media containing charcoal or peat. 
Table 2. Models that estimate ${ }^{\mathrm{z}}$ Laelia anceps Lindl. leaf, pseudobulb, and root dry mass (DM) in response to mixtures of charcoal $(\mathrm{Ch})$, volcanic rock $(\mathrm{Vr})$, and peat $(\mathrm{Pm})$ for growing media formulation at three nutrient solution concentrations measured as osmotic potential $\left(\psi_{\mathrm{S}}\right)$.

\begin{tabular}{|c|c|c|c|c|}
\hline $\begin{array}{l}\text { Growth } \\
\text { parameter }\end{array}$ & $\psi_{\mathrm{S}}(\mathrm{MPa})$ & Model & $P$ & Adjusted $R^{2}$ \\
\hline \multirow[t]{3}{*}{ Leaf DM (g) } & -0.051 & $1.830 \mathrm{Ch}+1.925 \mathrm{Vr}+2.074 \mathrm{Pm}-1.195 \mathrm{Vr} * \mathrm{Pm}$ & $<0.0001$ & 0.650 \\
\hline & -0.076 & $2.494 \mathrm{Ch}+1.925 \mathrm{Vr}+2.398 \mathrm{Pm}-1.195 \mathrm{Vr} * \mathrm{Pm}$ & & \\
\hline & -0.101 & $1.244 \mathrm{Ch}+1.925 \mathrm{Vr}+1.758 \mathrm{Pm}-1.195 \mathrm{Vr} * \mathrm{Pm}$ & & \\
\hline \multirow[t]{3}{*}{ Pseudobulb DM (g) } & -0.051 & $2.735 \mathrm{Ch}+2.159 \mathrm{Vr}+2.774 \mathrm{Pm}+2.163 \mathrm{Ch} * \mathrm{Pm}$ & $<0.0001$ & 0.704 \\
\hline & -0.076 & $2.346 \mathrm{Ch}+2.159 \mathrm{Vr}+2.676 \mathrm{Pm}-1.511 \mathrm{Ch} * \mathrm{Pm}$ & & \\
\hline & -0.101 & $1.001 \mathrm{Ch}+2.159 \mathrm{Vr}+1.900 \mathrm{Pm}+2.939 \mathrm{Ch} * \mathrm{Pm}$ & & \\
\hline \multirow[t]{3}{*}{ Root DM (g) } & -0.051 & $\begin{array}{l}2.591 \mathrm{Ch}+2.503 \mathrm{Vr}+2.030 \mathrm{Pm}-3.645 \mathrm{Ch} * \mathrm{Vr} \\
\quad-1.830 \mathrm{Ch} * \mathrm{Pm}+4.308 \mathrm{Ch}^{*} \mathrm{Vr}^{*}(\mathrm{Ch}-\mathrm{Vr})\end{array}$ & $<0.0001$ & 0.840 \\
\hline & -0.076 & $\begin{array}{l}1.708 \mathrm{Ch}+1.791 \mathrm{Vr}+2.111 \mathrm{Pm}+0.008 \mathrm{Ch} * \mathrm{Vr} \\
\quad-2.880 \mathrm{Ch} * \mathrm{Pm}+4.308 \mathrm{Ch}^{*} \mathrm{Vr}^{*}(\mathrm{Ch}-\mathrm{Vr})\end{array}$ & & \\
\hline & -0.101 & $\begin{array}{l}1.053 \mathrm{Ch}+1.692 \mathrm{Vr}+0.946 \mathrm{Pm}-0.360 \mathrm{Ch} * \mathrm{Vr} \\
+1.594 \mathrm{Ch}^{*} \mathrm{Pm}+4.308 \mathrm{Ch}^{*} \mathrm{Vr}^{*}(\mathrm{Ch}-\mathrm{Vr})\end{array}$ & & \\
\hline
\end{tabular}

${ }^{z}$ To estimate the growth parameter, select the model for the respective $\psi_{\mathrm{S}}$, substitute the proportion of each component in the media (charcoal, volcanic rock, or peat) as a fraction of 1 on the respective term $(\mathrm{Ch}, \mathrm{Vr}$, or Pm), and multiply it by the respective coefficient. For example, to estimate leaf DM of plants irrigated with a solution of $-0.076 \mathrm{MPa}$ and grown in a substrate formulated with $50 \%$ charcoal, $25 \%$ volcanic rock, and $25 \%$ peat, the model will be in the form: leaf $\mathrm{DM}=2.494(0.50)+1.925(0.25)+2.398(0.25)-1.195$ $(0.25)(0.25)=2.25 \mathrm{~g}$.
Furthermore, DM of pseudobulbs was highest in plants irrigated with solutions of $-0.051 \mathrm{MPa}$, especially in mixes with charcoal or $100 \%$ peat (Figs. 3A). Regardless of the $\psi_{\mathrm{S}}$ of the nutrient solution, Laelia grown in volcanic rock exhibited the lowest pseudobulb DM. Irrigation with solutions of $-0.076 \mathrm{MPa}$ resulted in decreased pseudobulb DM when plants were grown in a substrate that contained a mix of charcoal and peat or high proportions of charcoal (Fig. 3B). However, pseudobulb DM decreased when the $\psi_{\mathrm{S}}$ was decreased to $-0.101 \mathrm{MPa}$ and the medium was $100 \%$ peat (Fig. 3C). The media at which the plants produced greater than $80 \%$ of maximum pseudobulb DM are shown in the shaded area of the counterplot in Figure 3A when $\psi_{\mathrm{S}}$ was $-0.051 \mathrm{MPa}$ and in substrate mixtures of high proportions of either charcoal or peat, mixtures of charcoal and peat, and low proportions of volcanic rock.
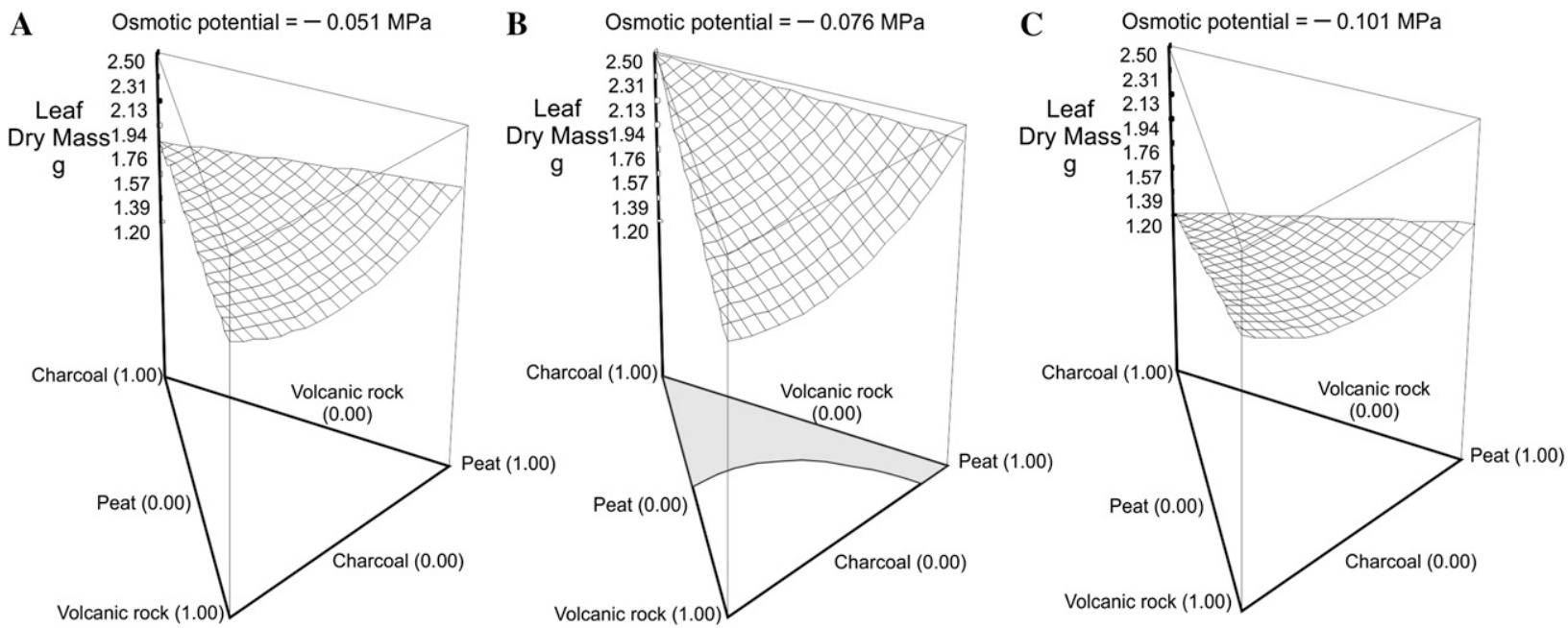

Fig. 2. Response surface exhibiting the effect of the proportion of charcoal: volcanic rock: peat in the growing media as affected by increasing fertilizer ratios in the nutrient solution measured as osmotic potential $\left(\psi_{\mathrm{S}}\right)-0.051(\mathbf{A}),-0.076(\mathbf{B})$, and $-0.101 \mathrm{MPa}(\mathbf{C})$ in Laelia anceps Lindl. leaf dry mass $(\mathrm{DM})$. The shaded area in $\mathbf{B}$ indicates the media predicted with the highest $20 \%$ of leaf DM in accordance with the estimated models.
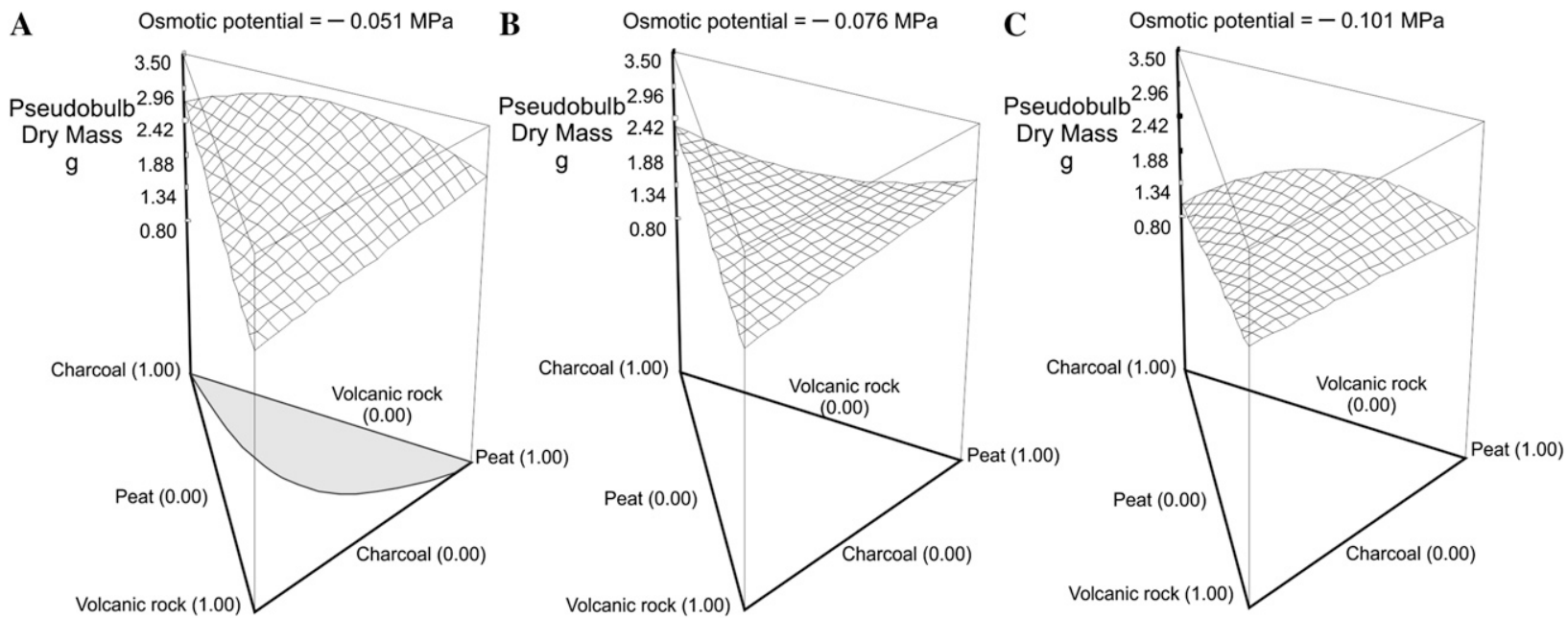

Fig. 3. Response surface exhibiting the effect of the proportion of charcoal: volcanic rock: peat in the growing media as affected by increasing fertilizer ratios in the nutrient solution measured as osmotic potential $\left(\psi_{\mathrm{S}}\right)-0.051(\mathbf{A}),-0.076(\mathbf{B})$, and $-0.101 \mathrm{MPa}(\mathbf{C})$ in Laelia anceps Lindl. pseudobulb dry mass $(\mathrm{DM})$. The shaded area in $\mathbf{A}$ indicates the media predicted with the highest $20 \%$ of pseudobulb DM in accordance with the estimated models. 
Growing media and $\psi_{\mathrm{S}}$ affected root DM (Table 2). In general, root growth was promoted when nutrient solution $\psi_{\mathrm{S}}$ was -0.051 $\mathrm{MPa}$ and the medium contained higher proportions of charcoal (Fig. 4A). Furthermore, decreasing the $\psi_{\mathrm{S}}$ of the nutrient solution to -0.076 (Fig. 4B) and $-0.101 \mathrm{MPa}$ (Fig. 4C) resulted in decreased root DM in all the substrate mixtures assessed, particularly when grown in media containing high proportions of charcoal. The media in which the plants produced greater than $80 \%$ of maximum root DM are shown in the shaded area of the counterplot in Figure 4A when $\psi_{\mathrm{S}}$ is $-0.051 \mathrm{MPa}$ and in mixes with high proportions of charcoal.

Analysis of nutrient concentration in the shoot (pseudobulb + leaves) following mixture experiments methodology rendered nonsignificant models. However, when the data were analyzed as a factorial experiment, a significant substrate, $\psi_{\mathrm{S}}$, and interaction effect were detected. Averaged across the growing media, decreasing the $\psi_{\mathrm{S}}$ of the nutrient solution resulted in increased shoot $\mathrm{N}$ and $\mathrm{K}$ concentrations (Table 3) and decreased concentration of $\mathrm{P}, \mathrm{Ca}, \mathrm{Mg}$ (Table 3), B, Mn, $\mathrm{Zn}$, and $\mathrm{Cu}$ (Table 4). Osmotic potential had no effect on Fe concentration (Table 4).

Table 5 shows the positive or negative sign of significant correlations $(P<0.05)$ between the media components or $\psi_{\mathrm{S}}$ with shoot nutrient concentration. Increasing charcoal proportion in the growing media resulted in increased shoot $\mathrm{Fe}$ and $\mathrm{Cu}$ concentration; however, increasing volcanic rock reduced $\mathrm{P}$ and $\mathrm{K}$ and increased $\mathrm{Mn}$ concentration. Increasing the proportion of peat was correlated with a decrease in plant Fe concentration. Decreasing the $\psi_{\mathrm{S}}$ of the nutrient solution resulted in increased shoot $\mathrm{N}$ and $\mathrm{K}$ concentration and reduced $\mathrm{Ca}, \mathrm{Mg}$, and micronutrients.

Leaf DM fit the following model $\left(R^{2}=\right.$ 0.970 , adjusted $R^{2}=0.925, P<0.0001, \mathrm{n}=$ $117)$, on which macronutrient:micronutrient or micronutrient:micronutrient ratios were calculated, regardless of the growing medium used or the $\psi_{\mathrm{S}}$ of the nutrient solution.

$$
\begin{aligned}
\operatorname{LDM}(g)= & -19.06-1.19^{\mathrm{E}-3} \mathrm{~N} / \mathrm{Fe} \\
& +1.33^{\mathrm{E}-3} \mathrm{~N} / \mathrm{Zn}-1.64 \mathrm{P} / \mathrm{B} \\
& +2.28^{\mathrm{E}-2} \mathrm{P} / \mathrm{Cu}-7.68^{\mathrm{E}-2} \mathrm{P} / \mathrm{Fe} \\
& -2.24^{\mathrm{E}-1} \mathrm{P} / \mathrm{Mn}+3.37^{\mathrm{E}-1} \mathrm{P} / \mathrm{Zn} \\
& -2.83^{\mathrm{E}-1} \mathrm{~K} / \mathrm{B}+3.53^{\mathrm{E}-3} \mathrm{~K} / \mathrm{Cu} \\
& +3.28^{\mathrm{E}-2} \mathrm{~K} / \mathrm{Fe}-1.98^{\mathrm{E}-2} \mathrm{~K} / \mathrm{Mn} \\
& -2.13^{\mathrm{E}-2} \mathrm{Ca} / \mathrm{Fe}+1.93^{\mathrm{E}-2} \mathrm{Ca} / \mathrm{Zn} \\
& +1.05 \mathrm{Mg} / \mathrm{B}-1.12^{\mathrm{E}-2} \mathrm{Mg} / \mathrm{Cu} \\
& -3.66^{\mathrm{E}-2} \mathrm{Mg} / \mathrm{Fe}-7.71^{\mathrm{E}-2} \mathrm{Mg} / \mathrm{Zn} \\
& +2.58 \mathrm{~B} / \mathrm{Fe}+4.74 \mathrm{~B} / \mathrm{Mn} \\
& -3.16 \mathrm{~B} / \mathrm{Zn}-2.57 \mathrm{Cu} / \mathrm{Fe} \\
& +4.00 \mathrm{Fe} / \mathrm{Zn}+3.65 \mathrm{Mn} / \mathrm{Zn}
\end{aligned}
$$

\section{Discussion}

Our results demonstrate that $L$. anceps responded to fertilization rate, because the nutrient solution of $-0.076 \mathrm{MPa}$ resulted in the highest leaf DM. Thus, the nutrient concentration of solutions at $-0.051 \mathrm{MPa}$ was not sufficient to maintain growth of Laelia. However, N, P, K, Mg, B, Fe, Mn, $\mathrm{Zn}$, and $\mathrm{Cu}$ of these plants were comparable to those irrigated with $-0.076 \mathrm{MPa}$ solutions, suggesting a higher level uptake of minerals by plants receiving the $-0.076 \mathrm{MPa}$ nutrient solution. The highest leaf $\mathrm{Ca}$ concentration was found in plants irrigated with solutions of high $\psi_{\mathrm{S}},-0.051 \mathrm{MPa}$, probably as a result of its lower fertilizer rate. Solutions of high $\psi_{\mathrm{s}}$ have comparatively more energy than solutions of low $\psi_{\mathrm{S}}$ and in turn allow a higher water uptake rate by roots and a mass flow of water and $\mathrm{Ca}$ to the roots (Yang et al., 2012). Calcium concentration exhibited by Laelia was within the sufficiency range reported for other orchid species such as Cattleya Lindl. (Mills and Benton Jones, 1996) and Phalaenopsis (Wang and Konow, 2002). Wang (1998) reported contrasting results in Phalaenopsis in that increases in nutrient concentration of the nutrient solution were related with increased leaf $\mathrm{Ca}$ concentration in plants grown in Douglas fir bark. However, the range of nutrient concentrations assessed by Wang (1998) was lower than those used in our study.

Decreased leaf DM in plants irrigated with solutions of high fertilizer rate $(-0.101$ $\mathrm{MPa}$ ) indicates that high nutrient solution concentration resulted in a detrimental effect, probably associated with the lower $\psi_{\mathrm{S}}$ of the nutrient solution. This may reflect the sensitivity of epiphytic orchids to salinity because in their natural habitat they are not exposed to high salinity (Wang, 1998). A number of floricultural species are reported as sensitive to high salinity in irrigation water (Grieve, 2011).

The low $\psi_{\mathrm{S}}$ of irrigation water is one of the components of salinity that causes growth reduction in plants (Munns and Tester, 2008) as a result of slower water uptake and decreased enlargement rate of cells and/or cell division (Munns and Tester, 2008; Zhang et al., 2010). In our study, we detected a marked reduction in leaf area of plants irrigated with solutions at the lowest $\psi_{\mathrm{S}}$ (data not shown), suggesting that either cell elongation or cell division, or both, were affected. The decreased leaf DM of plants irrigated with solutions of high nutrient concentration may also be the result of a nutrient imbalance, because plants with increased $\mathrm{N}$ and $\mathrm{K}$ (directly associated with the highest $\mathrm{N}$ and $\mathrm{K}$ concentrations of the irrigation solution) exhibited a decrease in $\mathrm{P}, \mathrm{Ca}, \mathrm{Mg}, \mathrm{B}, \mathrm{Mn}, \mathrm{Zn}$, and $\mathrm{Cu}$ concentration, suggesting a lower uptake rate and/or translocation from roots to leaves.

Plants of Phalaenopsis have been reported to exhibit enhanced growth and flower count when grown in a mixture of bark with media
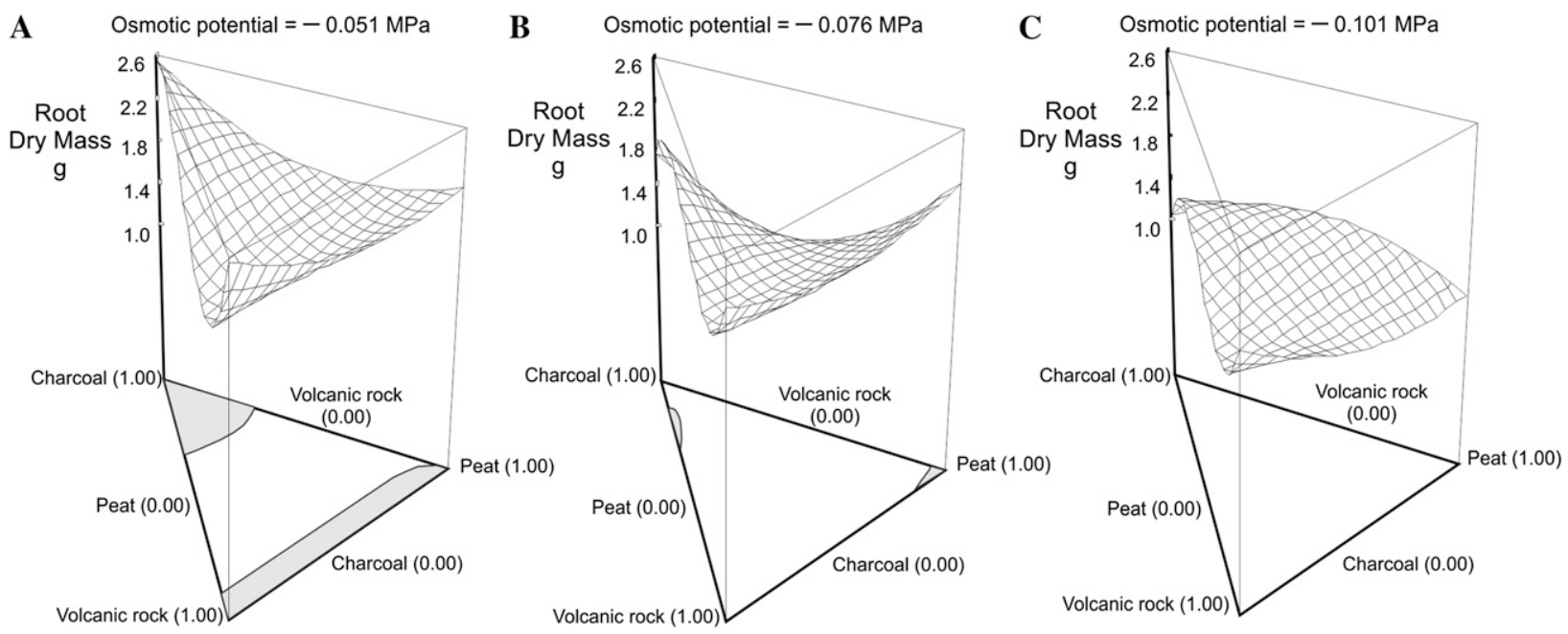

Fig. 4. Response surface exhibiting the effect of the proportion of charcoal: volcanic rock: peat in the growing media as affected by increasing fertilizer ratios in the nutrient solution measured as osmotic potential $\left(\psi_{\mathrm{S}}\right)-0.051(\mathbf{A}),-0.076(\mathbf{B})$, and $-0.101 \mathrm{MPa}(\mathbf{C})$ in Laelia anceps Lindl. root dry mass $(\mathrm{DM})$. The shaded area in A-B indicates the media predicted with the highest $20 \%$ of root DM in accordance with the estimated models. 
components of high water-holding capacity such as peat and vermiculite compared with plants grown in a medium composed exclusively of bark (Wang and Konow, 2002). Likewise, in our study, the response of Laelia to the nutrient solution concentration was influenced by the composition of the growing media. At optimum $\psi_{\mathrm{S}}(-0.076 \mathrm{MPa})$, the highest leaf DM was projected in mixtures containing either charcoal or peat or a combination of both plus a low proportion of volcanic rock.

The optimum growth of Laelia when cultivated in media containing high proportions of peat and charcoal suggests that this orchid demands a combination of components that provide a high water-holding capacity (peat), high aeration (charcoal), high cation exchange capacity (peat), and low apparent density (charcoal and peat). The volcanic rock used did not meet these standards because it had a low cation exchange capacity, a low water-holding capacity, and a high bulk density compared with peat and charcoal.

Charcoal has been successfully used as a component of growing media for orchid cultivation (Barman et al., 2012; Wang and Gregg, 1994) and other epiphytic species such as Anthurium andraeanum Linden ex André (Singh et al., 2009). Charcoal has been attributed with several beneficial effects when applied to soil, which may be effective when used for production purposes as a growing media component. According to Glaser et al. (2002) and Laird (2008), charcoal: 1) increases the capacity to absorb plant nutrients and reduces nutrient leaching; 2) may retain and slowly release most nutrients required for plant growth; 3) improves the bulk density of soils because it has a very low density, thus, root penetration is facilitated while water drainage and soil aeration are increased; and 4) it is a liming agent that reduces substrate acidification. Coarse materials are recommended when combined with a water-absorptive material for growing $P h a-$ laenopsis because it provides excellent air movement through the medium (Wang et al., 2007); such properties were provided by charcoal and peat in our study.

Shoot growth (leaf DM + pseudobulb DM) of Laelia was enhanced over root growth at $-0.076 \mathrm{MPa}$, whereas the lowest and highest $\psi_{\mathrm{S}}$ resulted in enhanced root growth over shoot growth (data not shown), corroborating that fertilization rate affected DM allocation. Similar results were reported by Wang (1998) in Phalaenopsis irrigated with water of increasing salinity. The decreased root growth under high fertilization rates may be the result of the lower $\psi_{\mathrm{S}}$ of the nutrient solution because it has been reported to exert an immediate effect on plants, including Phalaenopsis, by limiting root tip cell expansion (Munns and Tester, 2008; Wang, 1998). Apparently, our results are in contrast to those reported by Wang and Gregg (1994) because Phalaenopsis root $\mathrm{DM}$ increased dramatically when fertilized with increasing concentrations of $20 \mathrm{~N}-8.6 \mathrm{P}-$ $16.6 \mathrm{~K}$ from 0.25 to $1.0 \mathrm{~g} \cdot \mathrm{L}^{-1}$; we suggest that 
the fertilizer formula at the highest concentration used by Wang and Gregg (1994) rendered isosmotic solutions like in our study at the highest and, suggesting that our results with Laelia are comparable to those cited for Phalaenopsis. A differential fertility requirement by the two orchid species may also explain the contrasting results.

According to Wang (1998), increasing salinity of irrigation water linearly decreased Phalaenopsis root fresh weight regardless of the growing media, whereas shoot mass increased when grown in Douglas fir bark. However, when grown in a mixture of Douglas fir bark and peat, both shoot and root DM decreased as irrigation salinity increased. The contrasting response to salinity in irrigation water in orchids grown in different media may have been the result of the high cation exchange capacity of peat, which may increase the retention of sodium, chlorine, and other ions, as demonstrated by the higher EC of the leachate reported, thus rendering the toxicity effects of such ions.

The interaction between the growing media and the nutrient solution $\psi_{\mathrm{S}}$ indicates that shoot nutrient concentration was differentially affected by the combination of both factors. However, a model to explain the association between plant growth and nutrient concentration could not be estimated using mixture experiments methodology. Wang (1998) reported that increasing EC of irrigation water had no effect on the concentration of most macronutrients and micronutrients in leaves of Phalaenopsis, except for $\mathrm{Ca}$, when plants were grown in a media composed exclusively of Douglas fir bark. However, when plants were grown in a mixture of Douglas fir bark and peat, there was a reduction in $\mathrm{P}, \mathrm{K}$, $\mathrm{Fe}$, and $\mathrm{Cu}$ concentration and an increase in $\mathrm{Ca}, \mathrm{Mn}$, and $\mathrm{Zn}$.

In the present study, leaf DM of Laelia fit models on which macronutrient:micronutrient or micronutrient:micronutrient ratios were calculated, regardless of the growing media or the $\psi_{\mathrm{S}}$ of the nutrient solutions, suggesting that nutrient imbalance may be responsible for how plants respond to the growing media and fertilizer rate interaction. Diagnosing the nutrient status of a crop based on nutrient ratios, instead of using the critical sufficiency ranges, has been shown to be superior for the prediction of the response of plants to nutrient acquisition. The Diagnosis and Recommendation Integrated System is a method proposed by Beaufils (1973) that takes into account pairwise-calculated nutrient ratios and currently is a widely used tool for defining the nutritional status of crops. According to our results, the growth of orchid plants such as Laelia may also be predicted using the nutrient ratios approach rather than solely nutrient concentration.

All the terms of the model that explained leaf DM of Laelia estimated with our results included micronutrients in the ratios; however, the most influential coefficients (coefficients with the highest values) were those that included a micronutrient:micronutrient ratio, suggesting that an extremely fine balance in 
Table 5. Sign of the simple linear correlations that resulted significant $(P<0.05)$ among the proportion of the components of the growing media or the osmotic potential $\left(\psi_{\mathrm{S}}\right)$ of the nutrient solution and shoot concentration of macro- and micronutrients in Laelia anceps Lindl.

\begin{tabular}{|c|c|c|c|c|c|c|c|c|c|c|}
\hline & Nitrogen & Phosphorus & Potassium & Calcium & Magnesium & Boron & Iron & Manganese & Copper & Zinc \\
\hline Charcoal & & & & & & & + & & + & \\
\hline Volcanic rock & & - & - & & & & & + & & \\
\hline Peat & & & & & & & - & & & \\
\hline$\psi_{\mathrm{S}}$ & + & + & + & - & - & - & & - & - & - \\
\hline
\end{tabular}

the uptake of a given micronutrient in relation to other micronutrients was of major importance for adequate growth of Laelia.

The model suggests that (considering the negative coefficients as detrimental to leaf $\mathrm{DM}$, whereas the positive ones have an enhancing effect) an excess of B uptake compared with $\mathrm{Fe}, \mathrm{Mn}$, and $\mathrm{Zn}$ reduced leaf $\mathrm{DM}$, whereas a higher Fe uptake compared with $\mathrm{Cu}$ and $\mathrm{Zn}$, and an excess of Mn uptake compared with $\mathrm{Zn}$, resulted in increased leaf DM.

Macro- and micronutrient concentrations were more sensitive to fertilization rate than to the media components, as decreasing the $\psi_{\mathrm{S}}$ was associated with an increase in $\mathrm{N}$ and $\mathrm{K}$ concentration and a decrease in $\mathrm{P}, \mathrm{Ca}, \mathrm{Mg}$, and most micronutrients (despite the concentration of $\mathrm{B}, \mathrm{Mn}, \mathrm{Cu}$, and $\mathrm{Zn}$ in the nutrient solutions were maintained constant in all the nutrient solutions). The lower shoot concentration of most of the nutrients may be a consequence of the lower demand of Laelia because plants exhibited less growth when irrigated with solutions of low $\psi_{\mathrm{S}}$.

\section{Conclusions}

The maximum Laelia leaf growth was observed in plants irrigated with nutrient solutions at $-0.076 \mathrm{MPa}$ in growing media formulated with charcoal and peat, at varying proportions, as a result of the favorable combination of their physical and chemical properties. However, pseudobulb and root growth was greater when plants were irrigated with solutions of a lower fertilizer rate, $-0.051 \mathrm{MPa}$, and the media were formulated with low proportions of volcanic rock for maximum root growth. For maximum pseudobulb growth, the media should contain either a high charcoal or low volcanic rock content combined with peat. Fertilizer concentration and the growing media composition affected growth of Laelia by resulting in an imbalanced shoot nutrient concentration. These findings may serve as a basis for the commercial production of this threatened species.

\section{Literature Cited}

Ávila-Díaz, I. and K. Oyama. 2007. Conservation genetics of an endemic and endangered epiphytic Laelia speciosa (Orchidaceae). Amer. J. Bot. 94:184-193.

Ávila-Díaz, I., K. Oyama, C. Gómez-Alonso, and R. Salgado-Garciglia. 2009. In vitro propagation of the endangered orchid Laelia speciosa. Plant Cell Tissue Organ Cult. 99:335-343.

Barman, D., T.U. Bharathi, and R.P. Medhi. 2012. Effect of media and nutrition on growth and flowering of Cymbidium hybrid 'H.C. Aurora'. Indian J. Hort. 69:395-398.

Beaufils, E.R. 1973. Diagnosis and recommendation integrated system (DRIS). Soil Sci. Bull. $1: 1-132$.

Cornell, J.A. 2002. Experiments with mixtures. Designs, models, and the analysis of mixture data. 3rd Ed. Wiley, New York, NY.

Espejo-Serna, A. and A.R. López-Ferrari. 1998. Mexican monocots, a floristic synopsis I. Checklist, part VIII. Orchidaceae 2. Consejo Nacional de la Flor de México, A. C., Universidad Autónoma Metropolitana y Comisión Nacional para el Conocimiento y Uso de la Biodiversidad, México, D.F. [in Spanish].

Glaser, B., J. Lehmann, and W. Zech. 2002. Ameliorating physical and chemical properties of highly weathered soils in the tropics with charcoal-A review. Biol. Fertil. Soils 35:219230.

Grieve, C.M. 2011. Irrigation of floricultural and nursery crops with saline wastewaters. Isr. J. Plant Sci. 59:187-196.

Laird, D.A. 2008. The charcoal vision: A win-winwin scenario for simultaneously producing bioenergy, permanently sequestering carbon, while improving soil and water quality. Agron. J. 100:178-181.

Mills, H.A. and J. Benton Jones. 1996. Plant analysis handbook II. A practical sampling, preparation, analysis, and interpretation guide. MicroMacro Publishing, Inc., Athens, GA.

Molgo, I.E. and B.P.E. De Dijn. 2007. Orchids and orchid bees of the Brownsberg, Nassau and Lely ranges, p. 86-91. In: RAP bulletin of biological assessment: A rapid biological assessment of the Lely and Nassau plateaus,
Suriname. Conservation International. 23 Jan. 2013. <http://www.bioone.org/doi/book/10.1896/ 1-881173-98-4>

Munns, R. and M. Tester. 2008. Mechanisms of salinity tolerance. Annu. Rev. Plant Biol. 59: 651-681.

Ortega-Loeza, M.M., R. Salgado-Garciglia, C. Gómez-Alonso, and I. Ávila-Díaz. 2011. Acclimatization of the endangered Mexican epiphytic orchid, Laelia speciosa (H.B.K.). Schltr. European J. Environ. Sci. 1:48-54.

SAS Institute, Inc. 2001. SAS/STAT software changes and enhancements through release 8.0.2. SAS Institute, Cary, NC.

Singh, P., B.K. Dhaduk, S.L. Chawla, S. Alka, S.A. Aklade, J.R. Desai, and M.K. Yadav. 2009. Standardization of growing media for anthurium (Anthurium andreanum L.) cv. 'Flame' under protected conditions. J. Orn. Hort. 12: 101-105.

Soto, M.A. 1998. Updated list of orchids in México. Orquídea 11:233-277 [in Spanish].

Wang, Y.T. 1995. Medium and fertilization affect performance of potted Dendrobium and Palaenopsis. HortTechnology 5:234-237.

Wang, Y.T. 1996. Effect of six fertilizers on vegetative growth and flowering of Phalaenopsis orchid. Sci. Hort. 65:191-197.

Wang, Y.T. 1998. Impact of salinity and media on growth and flowering of a hybrid Phalaenopsis orchid. HortScience 33:247-250.

Wang, Y.T., M. Blanchard, R. Lopez, and E. Runkle. 2007. Growing the best Phalaenopsis. Part II: Media, transplanting, water and nutrient requirements. Orchids. American Orchid Society Bulletin 76:106-111.

Wang, Y.T. and L.L. Gregg. 1994. Medium and fertilizer affect the performance of Phalaenopsis orchids during two flowering cycles. HortScience 29:269-271.

Wang, Y.T. and E.A. Konow. 2002. Fertilizer source and medium compositions affect vegetative growth and mineral nutrition of a hybrid moth orchid. J. Amer. Soc. Hort. Sci. 127:442-447.

Yang, J., T. Punshon, M.L. Guerinot, and K.D. Hirschi. 2012. Plant calcium content: Ready to remodel. Nutrients 4:1120-1136.

Zhang, H., L.J. Irving, C. McGill, C. Matthew, D. Zhou, and P. Kemp. 2010. The effects of salinity and osmotic stress on barley germination rate: Sodium as an osmotic regulator. Ann. Bot. (Lond.) 106:1027-1035. 